\title{
Effects of Nishyinda, black pepper and cinnamon extract as growth promoter in broilers
}

\author{
M. R. Molla, M. M. Rahman*, F. Akter and M. Mostofa \\ Department of Pharmacology, Faculty of Veterinary Science, Bangladesh Agricultural \\ University, Mymensingh-2202, Bangladesh
}

\begin{abstract}
An extract of nishyinda (Vitex negundo) leaves, black pepper (Piper nigrum) and cinnamon (Cinnamomum verum) (polyherbal extract) were used as growth promoter in broilers. A total of 20 day-old broiler chicks were purchased and after seven days of acclimatization randomly divided into two equal groups. No vaccination schedule was practised and no antibiotics were added in rations. Group A served as control while group B was supplemented with polyherbal extract $1 \mathrm{~mL} /$ litre in drinking water. Weekly body weight gain up to six weeks was measured and blood tests were performed at 21 and 42 days. Polyherbal extract significantly $(\mathrm{P}<0.05)$ improved weight gain. There was no change in haematological parameters. It can be concluded that the polyherbal extract was safe as a growth promoter in broiler production without adverse effects on chicken health. (Bangl. vet. 2012. Vol. 29, No. 2, 69 - 77)
\end{abstract}

\section{Introduction}

Medicinal plants compete with synthetic drugs, and the majority have no residual effects (Tipu et al., 2006). Emerging health hazards are evident in animals and man by irrational use of antibiotics and antimicrobial growth promoters.

Herbal agents could serve as safer alternatives as growth promoters due to lower cost, reduced toxicity and minimum health hazards. Biological trials of certain herbal formulations as growth promoter have shown encouraging results and some of the reports have demonstrated improved weight gain and feed efficiency, lowered mortality, and increased immunity and viability in poultry (Kumar, 1991). Some herbal growth promoters exert therapeutic effects against liver damage due to feed contaminants like aflatoxin (Ghosh, 1992). Bangladesh is abundant in plants possessing interesting pharmacological properties, which await exploitation. Various herbal products are being used as growth promoters in poultry rations like nishyinda, black pepper and cinnamon. Antibiotics promote growth because of an effect on gut flora (de Man, 1975). The use of antibiotics as dietary growth promoters in poultry diets has reduced dramatically (WHO, 1997). Antimicrobial resistance in zoonotic pathogens including Salmonella, Escherichia coli (E. coli), and Enterococci in food animals is of special concern to human health because these are likely to transfer to humans (Endtz et al., 1991). In 2006 the European Commission banned the last four

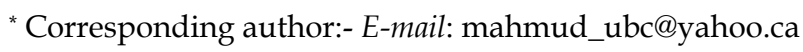


feed antibiotics (monensin sodium, salinomycin sodium, avilamycin, flavophospholipol). To minimize resistance, different agencies are in favour of banning these feed antibiotics (Hileman, 2002). The phasing out of antibiotic growth promoters will affect the poultry industry. There is a need to find alternatives. There are a number of alternatives such as enzymes, inorganic acids, probiotics, prebiotics, herbs, immunostimulants and management practices (Banerjee, 1998). Herbs and their essential oils have long been known for their antimicrobial activity (Juven et al., 1994; Chang, 1995). More recently, medicinal plant extracts have been developed or proposed for use in food as natural antimicrobials (Hsieh et al., 2001). Polyherbal extracts have been used worldwide for a range of medicinal properties like antibacterial, antiviral, antifungal, antiprotozoal, or hepato-protective without adverse effects (Kale et al., 2003; Chowdhury et al., 2009). Polyherbal products promote growth and feed efficiency of birds because of their antibacterial and hepatoprotective properties (Wankar, 2009).

Nishyinda (Vitex negundo L.) is a hardy plant, flourishing mainly in the Indian subcontinent. It possesses phyto-chemical secondary metabolites, which impart a variety of medicinal uses. The leaves of nishyinda may be applied locally to swellings from rheumatoid arthritis and sprains. The juice of the leaves is used for the treatment of foetid discharges. The principal constituents of the leaf juice are casticin, isoorientin, chrysophenol D, luteolin, p-hydroxybenzoic acid and D-fructose. Black pepper (Piper nigrum) is a flowering vine in the family Piperaceae, cultivated for its fruit, and used as a spice and seasoning. Dried ground pepper has been used for both its flavour and as a medicine, which is due to presence of piperine. Cinnamon (Cinnamomum zylenicum) is commonly used in the food industry. It has strong antibacterial, anti-candida, anti-ulcer, analgesic, antioxidant and hypocholesterolaemic activities (Mastura et al., 1999; Lin et al., 2003).

In Bangladesh, no comprehensive work has been done on the effects of plant extracts on body weight and performance in poultry. This study was designed to determine the effect of a polyherbal extract on live weight as a possible alternative to antibiotic feed additives.

\section{Materials and methods}

\section{Preparation of polyherbal extract}

The leaves of nishyinda were sun-dried for 10 days and oven-dried at $55-60^{\circ} \mathrm{C}$ for two days. The dried nishyinda leaves, black pepper and cinnamon were pulverized with a blender. A 25 (holes/inch) mesh diameter sieve was used to obtain fine dust, which was preserved in an airtight plastic container. Ten grams of nishyinda leaf powder mixed with $10 \mathrm{~g}$ black pepper and $10 \mathrm{~g}$ cinnamon was added to four litres distilled water, and boiled until the volume was reduced to three litres. Thus $30 \mathrm{~g}$ plant material in 3 litres of water that resulting the final concentration $1 \%$. 


\section{Collection and management of chickens}

Twenty day-old broiler chicks were collected from Nourish Hatchery and allowed to acclimatize for seven days. The body weights were taken. The birds were randomly divided into two equal groups. Group A was kept as control without any supplement while group B was supplemented with polyherbal extract $1 \mathrm{~mL} /$ litre in drinking water. The rations consisted of broiler starter mash from two to four weeks of age and broiler finisher mash from five to six weeks.

The birds were kept on a floor litter system in separate pens each measuring $0.9 \times 1.2$ metres. The pens were thoroughly cleaned, white-washed and disinfected before use. All the birds were provided same management. The chicks were brooded at $35^{\circ} \mathrm{C}$ during first week and the temperature was reduced by $3^{\circ} \mathrm{C}$ every week until the temperature reached room temperature at $25 \pm 1^{\circ} \mathrm{C}$. A weighed amount of the ration was offered twice a day and the left over feed was weighed to calculate feed consumption. Fresh clean water was made available at all times.

\section{Experimental design}

Body weight and feed consumption were measured weekly. Weekly growth rate, efficiency of feed utilization and mortality were calculated. Cost of production per $\mathrm{kg}$ in each group was calculated. At the end of the experiment, three birds from each group were picked randomly and slaughtered. The slaughtered birds were scalded in water at $82-88^{\circ} \mathrm{C}$ (Jull, 1976) then manually plucked. The weight of each carcass was recorded and dressing percentage calculated on the basis of dressed meat including giblets and skin. The heart, liver, gizzard, spleen and pancreas were weighed.

\section{Haematological parameters}

Blood samples were collected from wing vein of chicken of both groups at $21^{\text {st }}$ and $42^{\text {nd }}$ day and the following parameters were measured:

(a) Total erythrocyte count (TEC)

(b) Haemoglobin $(\mathrm{Hb})$

(c) Packed cell volume (PCV)

(d) Erythrocyte sedimentation rate (ESR)

\section{Determination of total erythrocyte count (TEC)}

Total erythrocyte count was done as described by Lamberg and Rothstein (1977). Well-mixed blood sample was drawn with red blood cell diluting pipette up to 0.5 marks. Outside of the tip of the pipette was wiped with cotton. The pipette was immediately filled with the red cell diluting fluid (Hayem's solution) up to 101 marks. The free end of the pipette was wrapped around with a rubber tube stretching to both ends and held with thumb and middle finger. The content of the pipette was mixed thoroughly by shaking for 3 - 5 minutes. The counting chamber was placed with special cover glass under microscope using low power (10x) objective. After discarding 2 or 3 drops of fluid from the pipette, a drop was placed to the edge of the 
cover glass on the counting chamber. Taking five larger squares (4 in the 4 corner and the centre) of the central large square, cells were counted from 80 small squares $(16 \times$ 5 ) under high power objective (45x). TEC was calculated as number of cells counted $x$ 10,000 and the result expressed in million $/ \mu \mathrm{L}$ of blood.

\section{Determination of haemoglobin concentrations $(\mathrm{Hb})$}

Hydrochloric acid $(\mathrm{HCl}) \mathrm{N} / 10$ was taken in a graduated tube up to two marks with the help of a dropper. Well-homogenized blood sample was drawn into a Sahli pipette up to $20 \mathrm{~cm}$ mark. The tip of the pipette was wiped with sterile cotton and the blood immediately transferred into a graduated tube containing hydrochloric acid. This blood and acid were thoroughly mixed by stirring with a glass stirrer. Acid haematin mixture formed. The tube was kept standing in the comparator for five minutes. Distilled water was added drop by drop. The solution was mixed well with a glass stirrer until the colour of the mixture resembled the standard colour of the comparator. The result was read in daylight by observing the height of the liquid in the tube. The result was expressed in $\mathrm{g} \%$. The procedure was matched by the Hellige haemometer method as described by Lamberg and Rothstein (1977).

\section{Determination of packed cell volume (PCV)}

Citrated well mixed blood was drawn into a Wintrobe pipette. The tip of the pipette was inserted up to the bottom of a clean, dry Wintrobe haematocrit tube, which was filled from the bottom. The tip of the pipette was kept under the column of blood to avoid foaming and the tube was filled to the $10 \mathrm{~cm}$ mark. The Wintrobe haematocrit tube was centrifuged for 30 minutes at $3000 \mathrm{rpm}$. The PCV was recorded by reading the graduation mark; the percent volume occupied by the haematocrit was calculated by using the following formula as described by Lamberg and Rothstein (1977).

$\mathrm{PCV} \%=\frac{\text { Height of the red cell volume in } \mathrm{cm}}{\text { Height of total blood in } \mathrm{cm}} \times 100$

\section{Determination of erythrocyte sedimentation rate (ESR)}

Fresh anticoagulant blood was taken into a Wintrobe haematocrit tube using special loading pipette up to zero mark. Excess blood above the mark was wiped away by sterile cotton. The filled tube stood vertically undisturbed for one hour, when the ESR was recorded from the top of the pipette. The result was expressed in $\mathrm{mm} /$ hour.

\section{Postmortem examination}

Three chickens from each group were slaughtered on $42^{\text {nd }}$ day of treatment. There was no significant pathological change.

\section{Statistical analysis}

The data were analysed statistically between control and treated groups of chicken by Student's t-test. 


\section{Results and Discussion}

\section{Effects of polyherbal extract supplementation}

The live weight gain of groups A and B for five weeks were $1550 \pm 21.2$ and $1660 \pm$ $32.8 \mathrm{~g}$, respectively. Supplementation of polyherbal extract resulted in significant $(\mathrm{P}<0.05)$ increase in mean live weight (Table 1). Similarly, Manwar el al. (2005) supplemented pearl millet extract $1-2 \mathrm{~mL} / \mathrm{kg}$ feed and reported significant increase in the live weight of broilers compared with control group.

Table 1. Live weight, weight gain, feed consumption and feed conversion ratio of broiler supplemented with polyherbal extract $1 \mathrm{ml} /$ Litre of drinking water from 2 to 6 weeks of age

\begin{tabular}{l|c|c}
\hline \multicolumn{1}{c|}{ Variable } & $\begin{array}{c}\text { Control (A) } \\
\text { Mean } \pm \text { SD }\end{array}$ & $\begin{array}{c}\text { Treatment (B) } \\
\text { Mean } \pm \text { SD }\end{array}$ \\
\hline Initial live weight (g) on $7^{\text {th }}$ day & $110 \pm 8.8$ & $110 \pm 8.7$ \\
& $(\mathrm{n}=10)$ & $(\mathrm{n}=10)$ \\
Final live weight (g) on $42^{\text {nd }}$ day & $1550 \pm 21.2$ & $1660 \pm 32 \cdot 8^{*}$ \\
& $(\mathrm{n}=8)$ & $(\mathrm{n}=8)$ \\
Weight gain (g) & $1440 \pm 21.2$ & $1550 \pm 22 \cdot 0^{*}$ \\
Feed consumption (g) & $3000 \pm 26.7$ & $3100 \pm 43.2^{*}$ \\
Feed conversion ratio & 1.94 & 1.87
\end{tabular}

*Mean values within the same row were significantly different $(\mathrm{P}<0.05)$

The birds supplemented with polyherbal (group B) gained higher live weight than the control group (Table 1). Supplementation of polyherbal had a significant effect on feed intake compared to the control (Table 1). There was no difference $(\mathrm{P}>0.05)$ in dressing percentage or relative gizzard and spleen weights between groups (Table 2).

Table 2. Dressing percentages, relative giblet and pancreas weights of broiler supplemented with polyherbal extract from 2 to 6 weeks of age

\begin{tabular}{l|c|cc}
\hline \multicolumn{1}{c|}{ Variables } & $\begin{array}{c}\text { Control (A) } \\
(\mathrm{n}=3)\end{array}$ & $\begin{array}{c}\text { Treatment (B) } \\
(\mathrm{n}=3)\end{array}$ \\
\hline Dressing percentage & 65.7 & 64.9 \\
Relative heart weight & 0.5 & 0.5 & \\
Relative gizzard weight & 1.4 & 1.4 & 75 \\
Relative liver weight & Molla et al. 2.6 & 2.6 & \\
Relative spleen weight & 0.1 & 0.1 & \\
Relative pancreas weight & 0.3 & 0.3 & , \\
\hline
\end{tabular}

Supplementation with polyherbal was more profitable than control group (Table 3): but the difference was not significant $(\mathrm{P}>0.05)$. Ahmad (2005) reported that dietary 
inclusion of polyherbal in the rations was beneficial in broiler production. Ihsan (2003) found that broilers fed turmeric fetched more profit than those without. Increase in the profit margin of birds fed rations containing herbal growth promoters may be attributed to better feed utilization.

Table 3. Economics of broiler production in polyherbal treated and control groups from 2 to 6 weeks of age

\begin{tabular}{lccc}
\hline \multicolumn{1}{c|}{ Descriptions } & Control (A) & Treatment (B) \\
\hline Cost/chick (Taka) & 50.0 & 50.0 \\
Average feed consumed (Kg)/chicks & 3.0 & 3.1 \\
Feed price/kg (Taka) & 40.0 & 40.0 \\
Cost of herbal growth promoter (Taka) & 0.0 & 3.0 \\
Feed cost (Taka) & 120.0 & 124.0 \\
Miscellaneous (Taka) & 16.0 & 16.0 \\
Total cost/broiler (Taka) & 186.0 & 194.0 \\
Average live weight (Kg) & $1.6 \pm 21.2$ & $1.7 \pm 32.8^{*}$ \\
& $(\mathrm{n}=8)$ & $(\mathrm{n}=8)$ \\
Sale price/Kg live wt. (Taka) & 140.0 & 140.0 \\
Sale price/broiler (Taka) & 217.0 & 232.4 \\
Net profit/broiler (Taka) & 31.00 & 38.40 \\
Profit/ Kg live weight (Taka) & 20.0 & 23.1 \\
\hline
\end{tabular}

*Mean values within the same row were significantly different $(\mathrm{P}<0.05)$

Effects of polyherbal extract on haematological parameters of broiler

Haematological parameters (RBC, Hb, PCV, ESR) on $21^{\text {st }}$ and $42^{\text {nd }}$ day did not show any significant difference $(\mathrm{P}>0.05)$ between the control and treated groups (Table 4$)$.

Supplementation with polyherbal improved the feed efficiency compared to control but the difference was not significant $(\mathrm{P}>0.05)$. Wankar et al. (2009) reported increased feed efficiency. Birds supplemented with polyherbal had significantly $(\mathrm{P}<0.05)$ higher body weight, gain in weight and feed consumption. These results may be due to antimicrobial and anti-protozoal properties (Kale et al., 2003; Bishnu et al., 2009), which help to reduce the microbial load in the gut of birds and improve the feed consumption of the birds.

Our results are in line with those reported by Siddig and Abdelati (2001) who fed rations containing turmeric and cinnamon, which produced higher weight gain. The improvement in weight gain of the birds using cinnamon in their rations may be due to the fact that cinnamon extract inhibits growth of intestinal bacteria such as $S$. aureus and E. coli as reported by Hanafy and Hatam (1991). When the load of these bacteria in the intestine is low, birds may absorb more nutrients, thus leading to the 
improvement in weight gain. The birds fed rations supplemented with polyherbal showed increased live weight compared to control, in agreement with Samanta and Dey (1991), who suggested that powdered cinnamon may be incorporated as a growth promoter in the ration of Japanese quails. Supplementation with polyherbal extract did not exhibit any effect on the dressing percentage. Broilers supplemented with nishyinda, black pepper and cinnamon from $2-6$ weeks showed significantly better performance as compared to the control group. These results could be explained by the finding that the extract suppresses pathogenic bacteria including Staphyloccoccus aureus, Mycobacterium sp., Salmonella paratyphi and Klebsiella pneumoniae (Kale et al., 2003; Bishnu et al., 2009; Mode et al., 2009).

Table 4. Effects of polyherbal extract on haematological parameters (RBC, $\mathrm{Hb}, \mathrm{PCV}$, ESR) of broiler

\begin{tabular}{|c|c|c|c|c|}
\hline Days & Parameters & Treatment & $\begin{array}{l}\text { Mean } \pm \text { SEM } \\
\quad(\mathrm{n}=10)\end{array}$ & $P$ value \\
\hline \multirow[t]{8}{*}{$21^{\text {st }}$ day } & $\mathrm{RBC}\left(\mathrm{mm}^{3}\right)$ & Control & $190.3 \pm 6 \cdot 4$ & 0.14 \\
\hline & & Polyherbal & $190.9 \pm 7.5$ & \\
\hline & $\mathrm{Hb}(\mathrm{g} \%)$ & Control & $6.0 \pm 0.10$ & 0.11 \\
\hline & & Polyherbal & $6.5 \pm 0 \cdot 1$ & \\
\hline & PCV (\%) & Control & $17 \cdot 4 \pm 0 \cdot 8$ & 0.419 \\
\hline & & Polyherbal & $20 \cdot 0 \pm 0 \cdot 6$ & \\
\hline & ESR $\mathrm{mm}$ in $1^{\text {st }}$ hours & Control & $11 \cdot 6 \pm 0.8$ & 0.126 \\
\hline & & Polyherbal & $8 \cdot 8 \pm 1 \cdot 0$ & \\
\hline $42^{\text {nd }}$ & $\mathrm{RBC}\left(\mathrm{mm}^{3}\right)$ & Control & $249.6 \pm 12 \cdot 8$ & 0.238 \\
\hline \multirow[t]{7}{*}{ Day } & & Polyherbal & $277 \cdot 6 \pm 12 \cdot 1$ & \\
\hline & $\mathrm{Hb}(\mathrm{g} \%)$ & Control & $7.0 \pm 0.2$ & 0.149 \\
\hline & & Polyherbal & $7 \cdot 7 \pm 0 \cdot 2$ & \\
\hline & PCV (\%) & Control & $17.1 \pm 0 \cdot 6$ & 0.218 \\
\hline & & Polyherbal & $22 \cdot 0 \pm 0 \cdot 3$ & \\
\hline & ESR $\mathrm{mm}$ in $1^{\text {st }}$ hours & Control & $7.1 \pm 0 \cdot 6$ & 0.236 \\
\hline & & Polyherbal & $5.3 \pm 1 \cdot 0$ & \\
\hline
\end{tabular}

Polyherbal had no significant effect on the haematological parameters (Table 4). Nagalakshmi et al. (1996); Gowda et al. (1998), however, reported that bitter principles of medicinal plants possess a strong influence on haematological traits particularly $\mathrm{PCV}$ and $\mathrm{Hb}$, depending on their nutritional status. The short duration of the 
experiment could explain this difference, as the lifespan of RBC is approximately 120 days. Our experiment was limited to 42 days in comparison to other work.

\section{Conclusions}

Treatment with nishyinda, black pepper and cinnamon extract produced a significant $(\mathrm{P}<0.01)$ increase in the live body weight. However there was no significant change in blood parameters in the treatment group suggesting that the herbal extracts had no harmful effect. It is concluded that supplementation with nishyinda, black pepper and cinnamon extract $1 \mathrm{~mL} / \mathrm{L}$ drinking water caused significant increase in live body weight and improvement in weight gain as compared to control group. Thus, polyherbal supplementation in broiler rations may be useful for the production of broiler as an alternative to commercial growth promoters.

\section{References}

Ahmad S 2005: Comparative efficiency of Turmeric, Garlic, Cinnamon and Kalongi as growth promoter in broiler. MSc (Hons.) Thesis, Department Poultry Sciences, University of Agriculture, Faisalabad, Pakistan.

Banerjee GC 1998: A Text Book of Animal Husbandry. $2^{\text {nd }}$ Edn. India publication, Delhi, India.

Bishnu J, Sunil L, Anju S 2009: Antibacterial Property of Different Medicinal Plants: Ocimum sanctum, Cinnamomum Zeylanicum, Xanthoxylum armatum and Origanum majorana. Kathmandu University Journal of Science, Engineering and Tecnology 5 143-150.

Chang HW 1995: Antibacterial effect of spices and vegetables. Food Industries 27 53-61.

Chowdhury NY, Islam W, Khalequzzaman M 2009: Insecticidal Activities of Stem Bark Extracts from Vitex negundo L. against Tribolium castaneum (Herbst). Journal of bio-sciences 17 63-70.

de Man JC 1975: The probability of most probable numbers. European Journal of Applied Microbiology 1 67-78.

Endtz HP, Rujis GH, Van Klingeren B 1991: Quinolon resistance in Campylobacter isolated from man and poultry following the introduction of fluroquinolones in veterinary medicine. Journal of Antimicorbials and Chemotheraputics 27 199-208.

Ghosh TK 1992: Efficiency of liver herbal product on counteracting aflatoxin on broiler birds. Indian Poultry Review 32 33-34.

Gowda SK, Verma SVS, Elangovan AV, Singh AD 1998: Neem (Azadirachta indica) kernel meal in the diet of white leghorn layer. British Poultry Science 39 648-652.

Hanafy MS, Hatam ME 1991: Studies on the anti-microbial activity of N. sativa seed (Black cumin). Journal of Ethnopharmacology 34 275-278.

Hileman B 2002: Debate over health hazards of putting antibiotics in animal feed heats up in the USA, Chemical and Engineering news.1999. Available at: http://www. organiconsumers.org/Toxic/bioticsinfeed.cfm Accessed August 2. 
Hsieh PC, Mau JL 2001: Antimicrobial effect of various combinations of plant extracts. Food Microbiology 18 35-43.

Ihsan K 2003: Effect of different levels of kalongi (N. sativa) seeds on the performance of broiler MSc (Hons.) Thesis, Department of Poultry Sciences, University of Agriculture, Faisalabad, Pakistan.

Jull AA 1976: Poultry Husbandry, 3rd Edn. Tata Mcgraw Hill Publishing Company Ltd., New Delhi, India

Juven BJ, Kanner J, Schved F, Weisslowicz H 1994: Factors that interact with the antibacterial action of thyme essential oil and its active constituents. Journal of Applied Bacteriology 76 626-631.

Kale BP, Kothekar MA, Tayade HP, Jaju JB, Mateeddin M 2003: Effect of aqueous extract of Azadirachta indica leaves on hepatotoxicity induced by antitubercular drugs in rats. Indian Journal of Pharmacology 35177.

Kumar OM 1991: Effect of Liv-52 syrup on broiler performance in North Eastern Region. Indian Poultry Review 31 37-38.

Lamberg SL, Rothstein R 1977: Laboratory Manual of Hematology and Urinalysis. Avi. Publishing Company, Inc, West Port Connecticut, USSR.

Lin CC, Wu SJ, Chang CH, Nu LT 2003: Antioxidant activity of Cinnamomum cassia. Phyto Research 17 726-730.

Manwar SJ, Thirumurugan P, Konwar D, Chidanandaiah, Karna DK 2005: Effect of Azadirachta indica leaf powder supplementation on broiler performance. Indian Veterinary Journal 84 159-162.

Mastura M, Nor Azah MA, Khozirah S, Mawardi R, Manaf AA 1999: Anticandidial and antidermatophytic activity of Cinnamomum species oils. Cytobios 98 17-23.

Mode SG, Funde ST, Waghmare SP, Kolte AY 2009: Effect of Herbal Immunodulator on Body weight gain in immunosuppressed broiler birds, Veterinary World 2 269-270.

Nagalakshmi D, Sastry VRB, Agrawal RC, Ketiyar DK, Verma SVS 1996: Performance of broiler chicks fed on alkali-treated (Azadirachta indica) kernel cake as a protein supplement. British Poultry Science 37 809-818.

Wankar AK, Shirvate RN, Bahiram KB, Dhenge SA, Jasutkar RA 2009: Effect of Neem (Azadirachta Indica) leaf powder supplementation on growth in broilers. Veterinary World 2 396-397.

Samanta AR, Dey A 1991: Effect of feeding garlic (A. sativum Linn.) as a growth promoter in Japanese quails (C. coturnix japonica) and its influence on dressing parameter. Indian Journal of Poultry Science 26142-145.

Siddig RM, Abdelati K 2001: Effect of dietary vitamin A and N. sativa on broiler chick's performance. In Proceeding: $10^{\text {th }}$ International Conference of Association for Tropical Veterinary Medicine and Livestock. Community and Environment, Copenhagen, Denmark.

Tipu MA, Akhtar MS, Anjum MI, Raja ML 2006: New dimension of medicinal plants as animal feed, Pakistan Veterinary Journal 26144-148.

WHO (World Health Organisation) meeting 1997: The medical impact of the use of antimicrobial in food animals. Report, Berlin, Germany, pp. 13-17. 